\title{
Analisis Kualitas Batu-bata Bersumber Bahan Tambahan Sampah Serbuk Gergaji dalam Berbagai Variasi Berat
}

\author{
Sri Slamet Mulyati ${ }^{1}$, Pujiono ${ }^{1}$, Teguh Budi Prijanto ${ }^{1}$, Elanda Fikri ${ }^{1}$ \\ ${ }^{1}$ Jurusan Kesehatan Lingkungan Poltekkes Kemenkes Bandung, Jalan Babakan Loa, 10A, Cimahi Utara. 40514
}

Info Artikel:Diterima Juli 2017 ; Disetujui Agustus 2017 ; Publikasi Oktober 2017

\begin{abstract}
ABSTRAK
Latar belakang: Serbuk gergaji kayu merupakan salah satu sumber sampah organik yang belum banyak dimanfaatkan. Keberadaannya tidak jauh di sekitar kita, relatif murah dan mudah mendapatkannya. Di beberapa negara luar seperti Uganda, Algeria, India dan lain-lain memanfaatkan serbuk gergaji ini untuk berbagai keperluan diantaranya sebagai bahan campuran batu-bata, pembentuk polimer selulosa nitrat, dan bahan adsorben polutan organik phenol. Penelitian sebelumnya memanfaatkan serbuk gergaji sebagai bahan tambahan campuran batu-bata (kaolin, tanah liat, serbuk gergaji) dengan rasio 90:70:40.

Metode: Penelitian ini merupakan eksperimen semu. Selanjutnya penulis tertarik untuk mengembangkan penelitian tersebut, untuk serbuk gergaji dibuat variasi berat bahannya, sementara yang lainnya tetap. Ukuran batubata dirancang berukuran $10,00 \times 5,00 \times 2,00 \mathrm{~cm}$. Untuk mengetahui kualitas batu-bata yang dihasilkan, penulis melakukan analisis kualitas terhadap batu-bata yang dihasilkan dengan berbagai variasi berat tersebut. Kualitas yang diuji baru pada tahapan daya serap air dan kandungan garam. Selain uji kualitas batu-bata juga dilakukan analisis valuasi ekonominya. Penelitian ini dilakukan pada skala laboratorium dengan harapan dapat dijadikan bahan acuan apabila akan diaplikasikan di lapangan.

Hasil: Hasil penelitian menunjukkan bahwa variasi berat serbuk gergaji antara rasio 20:70:90 dan 40:70:90 menunjukkan ada perbedaan peringkat rata-rata yang bermakna dalam hal daya serap batu-bata terhadap air begitu juga antara rasio 20:70:90 dan 60:70:90. Semua campuran batu-bata berdaya serap $>20 \%$, belum memenuhi standar kualitas berdasarkan SNI 15-2094-2000, namun semua campuran batu-bata mempunyai kadar garam $(\mathrm{NaCl})<50 \%$, ini artinya sudah memenuhi standar kualitas berdasarkan SNI 15-2094-2000.

Simpulan: Waktu pembakaran batu-bata dengan bahan tambahan serbuk gergaji lebih efisien 0,42 kalidibandingkan tanpa serbuk gergaji sehingga biaya lebih hemat.
\end{abstract}

Kata kunci: kualitas batu-bata, variasi berat, serbuk gergaji, sampah organik

\section{ABSTRACT}

Title: Quality Analysis Brick Sourced Sawdust in a Variety of Weight

Background:Sawdust as organic waste has not been widely used. Its presence close to us, cheap and easy to obtain. In others countries such as Uganda, Algeria, India and others, utilize sawdust for various purposes, such as mixed materials, forming polymers cellullose nitrate, and phenol pollutant adsorbent. Previous research utilizes sawdust as mixture of brick with a ratio of 90:70:40: (kaolin, clay,sawdust).

Methods:This was a quasi experiment design.Furthermore, authors interested in developing such research, sawdust made weight variation while others remain. Size bricks are designed measuring $10.00 \times 5.00 \times 2.00 \mathrm{~cm}$. To determine the quality of bricks produced, the authors analyze the quality of the bricks produced with a variety of weight of the sawdust. The quality of the tested new stage of absorption of water and salt content. In addition to testing the quality of bricks also performed a valuation analysis of its economy. This research was carried out on a laboratory scale with the hope can be used as a reference if it will be applied in the field.

Results:The results showed that weight variation sawdust between 20:70:90 and 40:70:90 ratio showed no difference in the average rating is meaningful in terms of absorption bricks to water as well as the ratio of 20:70:90 
and 60 : 70: 90. All blends brick absorbent> 20\%, yet meet the standards of quality based on SNI 15-2094-2000, but all of a mixture of brick had higher levels of salt $(\mathrm{NaCl})<50 \%$, this means that it meets quality standards based on SNI 15-2094 -2000.

Conclusion:Burning of bricks made from sawdust additional more efficient, \pm 0.42 times from the time of burning bricks without straw, making it more cost-effective.

Keywords : brick quality, weight variation, sawdust, garbage

\section{PENDAHULUAN}

Serbuk gergaji yang dibuang ke area tanah atau pelataran terbuka bergitu saja dapat menimbulkan pencemaran air akibat resapan leachatnya yang mengandung lignin, asam lemak, dan materi toksik lainnya. ${ }^{1,2}$

Serbuk gergaji merupakan turunan dari bagian kayu yang halus (sofwood) dan bagian kayu yang kasar (hardwood), atau kombinasi keduanya. Setiap jenis kayu tentunya mempunyai struktur yang berbeda-beda namun secara umum mempunyai komposisi dasar yang sama yaitu terdiri atas unsur-unsur selulosa, lignin, hemiselulosa, dan holoselulosa. ${ }^{3,4}$ Atas dasar tersebut, ada peluang untuk melakukan transformasi serbuk gergaji menjadi sumber biologi yang beramanfaat dalam aplikasi industri

Berbagai penelitian yang menunjukkan pemanfaatan serbuk gergaji diantaranya adalah pembentukan bahan polimer selulosa nitrat sebagai pengganti unsur-unsur yang bukan golongan selulosa. ${ }^{5}$ Penelitian lainnya adalah menjadikan serbuk gergaji sebagai adsorben dalam menurunkan kandungan phenol dalam air limbah. ${ }^{6}$ Pemanfaatan penting lainnya adalah menjadikan serbuk gergaji sebagai bahan tambahan dalam pembuatan batu-bata. Bahan yang digunakan dalam pembuatan batu-bata ini adalah kaolin, tanah liat, dan serbuk gergaji dengan rasio berat 9:7:4. ${ }^{7}$ Batubata yang baik tentunya mempunyai persyaratan kualitas diantaranya adalah daya serap air, kekerasan, bentuk dan ukuran, bunyi, kandungan garam, dan lainlain. Uji daya serap air dan kandungan garam merupakan uji kuantitatif sehingga lebih objektif dan memungkinkan untuk dapat dilakukan di laboratorium. Berdasarkan hal di atas penulis tertarik untuk melakukan analisis sejauh mana kualitas batu bata bersumber bahan tambahan serbuk gergaji kayu dalam berbagai variasi berat ( dari sisi daya serap air dan kandungan garamnya).

\section{MATERI DAN METODE}

Jenis penelitian yang digunakan adalah eksperimen semu dengan skala laboratorium untuk diaplikasikan di lapangan. Penelitian ini menggunakan desain sebelum dan sesudah satu kelompok atau One Group Pretest-Postest. Langkah-langkah yang dilakukan dalam penelitian ini adalah: a. Mengumpulkan sampah serbuk gergaji di sekitar komplek perumahan Margaasih Kabupaten Bandung.

b. Melakukan pembuatan batu-bata berukuran $10 \mathrm{x}$ $5 \times 2 \mathrm{~cm}$ dengan menggunakan berbagai variasi berat serbuk gergaji dalam kombinasi bahan baku (kaolin, tanah liat, dan serbuk gergaji)

c. Menghitung daya serap air batu-bata berbahan baku serbuk gergaji

d. Menghitung kandungan garam batu-bata berbahan tambahan serbuk gergaji.

e. Melakukan penetapan kualitas batu-bata berbahan tambahan serbuk gergaji.

Populasi dalam penelitian ini adalah seluruh sampah serbuk gergaji yang dihasilkan komplek perumahan Margaasih Kabupaten Bandung. Sedangkan sampel adalah sebagian sampah organik serbuk gergaji yang diambil untuk dijadikan bahan tambahan pembuatan batu-bata. Selanjutnya dipilah dari pengotor tanah dan ditimbang.

Metoda pengambilan sampel yang digunakan adalah grab sample atau sampel sesaat, dimana volume timbulan sampah serbuk gergaji diperkirakan sudah memenuhi syarat secara kuantitas untuk penelitian

\section{HASIL DAN PEMBAHASAN}

Variasi Berat Sampah Serbuk Gergaji Terhadap Persentase Daya Serap Air Batu-bata

Kualitas batu-bata bersumber bahan tambahan sampah serbuk gergaji dapat dilihat pada tabel 5.1. Sebagai penelitian awal, kajian kualitas batu-bata dibatasai pada parameter daya serap air dan kandungan garam.

Tabel 1 menunjukkan bahwa kadar kering batu-bata (berat awal) yang tidak mengandung campuran kaolin dan serbuk gergaji (kontrol) mempunyai berat rata-rata 125 gram. Berat batu-bata paling ringan rata-rata 20,83 gram ditunjukkan oleh perlakuan 1 yang merupakan campuran antara serbuk gergaji, tanah liat, dan kaolin dengan rasio 20:70:90. Sementara pada perlakuan 2 dan 3 menunjukkan berat rata-rata yang tidak jauh berbeda, selisih keduanya adalah 0,83 gram.

Persentase daya serap batu-bata terhadap air baik perlakuan 1, 2, maupun 3 menunjukkan nilai rata-rata daya serap $>100 \%$, sedangkan untuk kontrol $<100 \%$ $(56,19 \%)$. Seperti halnya berat batu-bata paling ringan, persentase daya serap tertinggi pun ditunjukkan oleh perlakuan 1 yang merupakan campuran antara serbuk gergaji, tanah liat, dan kaolin dengan rasio 20:70:90. 
Tabel 1

Persentase Daya Serap Air Batu-bata Bersumber Bahan Tambahan Serbuk Gergaji

\begin{tabular}{|c|c|c|c|c|c|c|c|c|c|c|c|c|}
\hline \multirow[t]{3}{*}{ Replikasi } & \multicolumn{3}{|c|}{ Kontrol } & \multicolumn{3}{|c|}{ Perlakuan 1} & \multicolumn{3}{|c|}{ Perlakuan 2} & \multicolumn{3}{|c|}{ Perlakuan 3} \\
\hline & & & & & sio $20: 70$ & & & $\operatorname{sio} 40: 70$ & & & io $60: 7$ & 0:90 \\
\hline & $\begin{array}{c}\text { awal } \\
\text { (gr) }\end{array}$ & $\begin{array}{c}\text { akhir } \\
\text { (gr) }\end{array}$ & $\%$ & $\begin{array}{c}\text { awal } \\
\text { (gr) }\end{array}$ & $\begin{array}{c}\text { akhir } \\
\text { (gr) }\end{array}$ & $\%$ & $\begin{array}{c}\text { awal } \\
\text { (gr) }\end{array}$ & $\begin{array}{c}\text { akhir } \\
\text { (gr) }\end{array}$ & $\%$ & $\begin{array}{c}\text { awal } \\
\text { (gr) }\end{array}$ & $\begin{array}{c}\text { akhir } \\
\text { (gr) }\end{array}$ & $\%$ \\
\hline 1 & 120 & 190 & 58.33 & 20 & 120 & 500.0 & 40 & 100 & 150.0 & 40 & 110 & 175.0 \\
\hline 2 & 130 & 200 & 53.85 & 20 & 130 & 500.0 & 40 & 10 & 175.0 & 40 & 110 & 175.0 \\
\hline 3 & 120 & 190 & 58.33 & 20 & 120 & 500.0 & 35 & 110 & 214.29 & 40 & 110 & 175.0 \\
\hline 4 & 130 & 190 & 46.15 & 20 & 120 & 500.0 & 40 & 110 & 175.0 & 30 & 110 & 266.67 \\
\hline 5 & 130 & 200 & 53.85 & 25 & 120 & 380.0 & 30 & 110 & 266.67 & 40 & 110 & 175.0 \\
\hline 6 & 120 & 200 & 66.67 & 20 & 120 & 500.0 & 40 & 110 & 150.0 & 40 & 110 & 175.0 \\
\hline Rata-rata & 125 & 195 & 56,19 & 20,83 & 121,67 & 480 & 37,50 & 108,33 & 188.49 & 38,33 & 110 & 190,28 \\
\hline
\end{tabular}

Data tidak berdistribusi normal sehingga dilakukan uji kruskal wallis. Hasil uji statistik menunjukkan bahwa ada perbedaan peringkat rata-rata yang bermakna dalam hal daya serap batu-bata terhadap air antara variasi berat serbuk gergaji rasio 20:70:90 dengan rasio 40:70:90 ( $p$ value $=0,003)$. Begitu juga variasi berat serbuk gergaji rasio 20:70:90 dengan rasio 60:70:90 ( $p$ value $=0,002)$ menunjukkan perbedaan peringkat ratarata yang bermakna dalam hal daya serap batu-bata terhadap air. Sebaliknya variasi berat serbuk gergaji rasio 40:70:90 dengan rasio 60:70:90 tidak menunjukkan perbedaan peringkat rata-rata yang bermakna dalam hal daya serap batu-bata terhadap air $(p$ value $=0,654)$.

1. Variasi Berat Sampah Serbuk Gergaji Terhadap Kandungan Garam Air Batu-bata

Kualitas kandungan garam batu-bata bersumber bahan tambahan sampah serbuk gergaji dapat dilihat pada tabel2. Hasil observasi secara fisik kandungan garam yang terdapat pada batu-bata adalah berdasarkan keberadaan bercak putih yang menutupi sebagian atau seluruh batu-bata yang tidak direndam air selama pengujian. Secara keseluruhan baik batu-bata dengan ataupun tanpa tambahan serbuk gergaaji menunjukkan keberadaan bercak putih yang hanya sedikit saja $(<$ 50\%). Seberapa besar jumlah kandungan garamnya, penelitian dikembangkan dengan melakukan pengujian kandungan garam tertentu yang relatif sederhana yaitu garam $\mathrm{NaCl}$ dengan metode titrasi. Berikut adalah kandungan garam $\mathrm{NaCl}$ yang terdapat dalam setiap batu-bata.

Data juga tidak berdistribusi normal sehingga dilakukan uji kruskal wallis. Hasil uji statistik menunjukkan bahwa tidak ada perbedaan peringkat rata-rata yang bermakna dalam hal kandungan garam batu-bata antara variasi berat serbuk gergaji rasio 20:70:90, rasio 40:70:90 dan rasio 60:70:90 ( $p$ value $>0,05)$. Di luar kajian daya serap batu-bata terhadap air dan kandungan garam, ada data lain yang didapat dari penelitian ini yaitu densitas atau kerapatan semu batu-bata. Berdasarkan SNI, densitas atau kerapatan semu minimum bata merah pasangan dinding adalah 1,2 gram $/ \mathrm{cm}^{3}$. Batu-bata tanpa campuran serbuk gergaji dan kaolin rata-rata mempunyai kerapatan semu sebesar 1,25 gram $/ \mathrm{cm}^{3}$. Sedangkan kerapatan semu batu-bata dengan variasi serbuk gergaji rasio 20:70:90, rasio 40:70:90 dan rasio 60:70:90, masing-masing adalah $0,208 \mathrm{gram} / \mathrm{cm}^{3}, 0,375 \mathrm{gram} / \mathrm{cm}$

Tabel 2

Persentase Garam NaCl Batu-bata Bersumber Bahan Baku Tambahan Serbuk Gergaji

\begin{tabular}{|c|c|c|c|c|c|c|c|c|c|c|c|c|}
\hline \multirow[t]{3}{*}{ Replikasi } & \multicolumn{3}{|c|}{ Kontrol } & \multicolumn{3}{|c|}{ Perlakuan 1} & \multicolumn{3}{|c|}{ Perlakuan 2} & \multicolumn{3}{|c|}{ Perlakuan 3} \\
\hline & & & & \multicolumn{3}{|c|}{ Rasio 20:70:90 } & \multicolumn{3}{|c|}{ Rasio 40:70:90 } & \multicolumn{3}{|c|}{ Rasio 60:70:90 } \\
\hline & $\begin{array}{c}\text { awal } \\
\text { (gr) }\end{array}$ & $\begin{array}{c}\text { akhir } \\
\text { (gr) }\end{array}$ & $\%$ & $\begin{array}{c}\text { awal } \\
\text { (gr) }\end{array}$ & $\begin{array}{c}\text { akhir } \\
\text { (gr) }\end{array}$ & $\%$ & $\begin{array}{c}\text { awal } \\
\text { (gr) }\end{array}$ & $\begin{array}{c}\text { akhir } \\
\text { (gr) }\end{array}$ & $\%$ & $\begin{array}{c}\text { awal } \\
\text { (gr) }\end{array}$ & $\begin{array}{c}\text { akhir } \\
\text { (gr) }\end{array}$ & $\%$ \\
\hline 1 & 120 & 190 & 19.65 & 20 & 120 & 29.48 & 40 & 100 & 22.93 & 40 & 110 & 26.21 \\
\hline 2 & 130 & 200 & 22.93 & 20 & 130 & 19.65 & 40 & 110 & 29.48 & 40 & 110 & 26.21 \\
\hline 3 & 120 & 190 & 26.21 & 20 & 120 & 22.93 & 35 & 110 & 26.21 & 40 & 110 & 29.48 \\
\hline 4 & 130 & 190 & 22.93 & 20 & 120 & 32.76 & 40 & 110 & 26.21 & 30 & 110 & 22.93 \\
\hline 5 & 130 & 200 & 22.93 & 25 & 120 & 22.93 & 30 & 110 & 22.93 & 40 & 110 & 26.21 \\
\hline 6 & 120 & 200 & 26.21 & 20 & 120 & 29.48 & 40 & 110 & 22.93 & 40 & 110 & 29.48 \\
\hline
\end{tabular}


Batu-bata tanpa bahan campuran serbuk gergaji dan kaolin mempunyai nilai rata-rata daya serap terhadap air sebesar 56,19\%. Batu-bata dengan kombinasi bahan serbuk gergaji, tanah liat, dan kaolin dengan rasio 20:70:90 mempunyai daya serap paling tinggi terhadap air, rata-rata mencapai $480 \%$. Namun demikian penambahan berat serbuk gergaji menjadi 40 gram dan 60 gram dengan komposisi berat tanah liat dan kaolin tetap, tidak menjadikan daya serapnya terhadap air menjadi semakin tinggi. Masing-masing besar persentase keduanya rata-rata adalah $188,49 \%$ dan $190,28 \%$.

Tanah liat mempunyai berat jenis yang lebih besar dibandingkan dengan serbuk gegaji. Semakin tinggi berat jenis semakin baik konduktivitas termalnya. Konduktivitas termal adalah suatu besaran intensif bahan yang menunjukkan kemampuannya untuk menghantarkan panas. Faktor-faktor yang mempengaruhi konduktivitas termal diantaranya adalah suhu, kandungan uap air, berat jenis dan keadaan pori-pori bahan. Saat batu-bata bersumber bahan baku tanah liat dipanaskan, batu-bata tersebut mampu menghantarkan dan melepaskan panas yang diterimanya dengan baik ke lingkungan. Sementara serbuk gergaji mempunyai struktur yang berongga besar dibandingkan dengan tanah liat, berat jenis yang lebih ringan dibandingkan dengan tanah liat, sehingga serbuk gergaji bukanlah sebagai konduktor yang baik, melainkan sebagai isolator yang baik. Kemampuan material serbuk gergaji menahan panas lebih lama saat dipanaskan, disamping itu dengan strukturnya yang berongga, menjadikan batu-bata berbahan tambahan serbuk gergaji lebih ringan dan lebih banyak menyerap air dibandingkan dengan tanah liat.

Penambahan berat serbuk gergaji menjadi 40 gram dan 60 gram dengan komposisi berat tanah liat dan kaolin tetap, tidak menjadikan daya serapnya terhadap air menjadi semakin tinggi. Hal ini berbeda dengan temuan penelitian yang dilakukan di Uganda tahun 2014, bahwa penambahan material serbuk gergaji menurunkan konduktivitas termal. Seperti kita ketahui bahwa konduktivitas termal ini akan berpengaruh pada sebaran panas batu-bata saat dipanaskan. Walaupun secara fisik batu-bata berbahan tambahan serbuk gergaji ini lebih ringan, lebih cepat merata panasnya, namun berdasarkan SNI 15-2094-2000 bahwa penyerapan air maksimum bata merah pasangan dinding adalah $20 \% .^{8}$ Hasil penelitian menunjukkan bahwa secara keseluruhan daya serap batu-bata terhadap air tidak memenuhi syarat kualitas berdasarkan SNI.

Sesungguhnya persyaratan dalam SNI 15-2094-2000 tidak menyebutkan secara spesifik jenis kandungan garam yang ditolelir adanya dalam sebuah batu-bata. Namun demikian kenyataan di lapangan untuk uji kandungan garam hanya dengan melihat keberadaan bercak putih saja yang menyelimuti permukaan bata sangatlah subjektif, maka penelitian ini dikembangkan dengan melakukan pemeriksaan jenis garam tertentu yaitu $\mathrm{NaCl}$. Metode yang digunakan cukup mudah dan sederhana yaitu dengan cara titrasi.

Kandungan garam $\mathrm{NaCl}$, baik untuk batu-bata berbahan baku tanah liat maupun berbahan tambahan serbuk gergaji berbagai rasio, secara keseluruhan memenuhi syarat $(<50 \%)$. Berdasarkan SNI 15-20942000 bahwa kadar garam maksimum tidak boleh menyebabkan lebih dari 50\% permukaan batu-bata tertutup dengan tebal akibat pengkristalan garam. Sesungguhnya garam yang mudah larut dan membahayakan adalah golongan Magnesium Sulfat (MgSO4), Natrium Sulfat (Na2SO4), dan Kalium Sulfat (K2SO4). Keberadaan garam dalam batu-bata menjadi sesuatu yang penting dikaji karena terkait "salt attack". Salt attack adalah suatu kondisi di mana suatu bangunan terancam rusak oleh karena serangan kandungan garam yang terdapat dalam batu-bata. Seperti kita ketahui bahwa kandungan garam ini bersifat menarik dan menyerap air, dan inilah yang menyebabkan bangunan cepat rusak atau mengalami keparahan. ${ }^{9}$

Hasil penelitian skala laboratorium menunjukkan bahwa persyaratan kualitas untuk daya serap batu-bata berbahan tambahan serbuk gergaji dengan variasi rasio seperti tersebut di atas belum memenuhi syarat berdasarkan SNI. Namun demikian tidak menutup kemungkinan untuk dilakukan kajian valuasi ekonominya. Kajian valuasi ekonomi batu-bata berbahan tambahan serbuk gergaji dalam penelitian ini ditinjau dari sisi efisiensi penggunaan bahan bakar. Seperti kita ketahui bahwa serbuk gergaji mempunyai pori-pori yang lebih besar dibandingkan dengan tanah liat. Batu-bata berbahan tambahan serbuk gergaji mempunyai konduktivitas termal yang rendah, oleh sebab itu batu-bata berbahan tambahan serbuk gergaji menjadi lebih cepat panas, lama menahan panas. Kondisi ini memberi keuntungan jika diaplikasikan di lapangan, dengan gambaran perhitungan sederhana berikut ini :

- Pemanasan batu-bata berbahan baku tanah liat :

2 hari suhu normal pembakaran

- Jumlah batu-bata : 70.000 bata

- Bahan bakar solar 70 liter x @ Rp 6.500 : Rp 445.000,-

- Pemanasan batu-bata berbahan tambahan serbuk gergaji $\quad: 4$ jam suhu $\pm 100{ }^{\circ} \mathrm{C}$

- Jumlah batu-bata : 70.000 bata

- Bahan bakar solar 20/48 jam x 70 liter x@ @p $6.500 \quad: \operatorname{Rp} 189.585,5$

Selisih pengeluaran

: Rp 190.000,-

: Rp 255.000,-

\section{SIMPULAN}

Batu-bata berbahan tambahan serbuk gergaji dengan rasio berat antara serbuk gergaji, tanah liat, dan kaolin 
20:70:90, 40:70:90 dan 60:70:90 gram, semuanya berdaya serap $>20 \%$, belum memenuhi standar kualitas berdasarkan SNI 15-2094-2000, walaupun kualitas fisik batu-bata tersebut secara keseluruhan mempunyai struktur yang sangat ringan.

Batu-bata berbahan tambahan serbuk gergaji dengan rasio berat antara serbuk gergaji, tanah liat, dan kaolin 20:70:90, 40:70:90 dan 60:70:90 gram, semuanya mempunyai kadar garam $(\mathrm{NaCl})<50 \%$, ini artinya sudah memenuhi standar kualitas berdasarkan SNI 152094-2000, walaupun spesifikasi jenis garam dalam standar tersebut tidak disebutkan.

Variasi berat serbuk gergaji antara rasio 20:70:90 dan 40:70:90 menunjukkan ada perbedaan peringkat ratarata yang bermakna dalam hal daya serap batu-bata terhadap air begitu juga antara rasio 20:70:90 dan 60:70:90.Pembakaran batu-bata berbahan tambahan serbuk gergaji lebih effisien, $\pm 0,42$ kali dari waktu pembakaran batu-bata tanpa serbuk gergaji, sehingga lebih hemat biaya.

\section{DAFTAR PUSTAKA}

1. Ikem A, Osibanjo O, Sridhar M K C and Sobande A, Water Air Soil pollut., 2002, 140(1-4), 307 - 333.
2. Adekunle I M, Arowolo T A, Ndahi N P, Bello B and Owolabi D A, Annals of Environmental Science, 2007b, 1, 23-34.

3. Harris J F, Wood as a Chemical Raw Material. The Chemistry of Wood; Interscience, New York: USA, 1963.

4. Belewu M A, Afr J Biotechnol., 2006, 5(19), 1763 -1764 .

5. Adekunle IM, Production of Cellulose Nitrate EJournal of Chemistry2010, 7(3), 709-716

6. Adekunle IM, The use of sawdust as by product adsorbent of organic pollutant from wastewater: adsorption of phenol . Energy Procedia 18 ( 2012 ) 905 - 914. Department of Environmental Management and Toxicology, University of Agriculture, P.M.B. 2240, Abeokuta, Nigeria.

7. Bwayo E, Obwoya S.K. Thermal Conduvtivity Of Insulation Brick Developed From Sawdust And Selected Uganda Clays.2014Department of Physics, Kyambogo University, Kampala, Uganda. 2014;Vol.03

8. SNI 15-2094-2000 tentang Persyaratan Batu-bata 